\title{
ADAPTACE ČESKÉHO PRÁVNÍHO ŘÁDU NA ŽKÍZENÍ ÚŘADU EVROPSKÉHO VEŘEJNÉHO ŽALOBCE
}

\author{
JIŘÍ PAVLÍK*
}

\begin{abstract}
Adaptation of the Czech Law Regulation to the establishment of the European Public Prosecutor's Office

Council Regulation (EU) 2017/1939 of 12 October 2017 implementing enhanced cooperation on the establishment of the European Public Prosecutor's Office ("the EPPO") was published in the Official Journal of the European Union on 31 October 2017. The Czech Republic decided to establish enhanced cooperation in this area and to participate in the project of the European Public Prosecutor's Office. This has caused a need to prepare Czech legal order for the Regulation in question to be applied without any major problems. This paper aims to capture, emphasize and explain at least the basic and most important changes brought about by the adaptation of the Czech legal order.
\end{abstract}

Keywords: European Public Prosecutor's Office; EPPO; public prosecution; Public Prosecutor's Office; criminal proceedings

Kličcvá slova: Úřad evropského veřejného žalobce; EPPO; veřejná žaloba; státní zastupitelství; trestní rízení

DOI: $10.14712 / 23366478.2019 .37$

\section{1. ÚVOD}

Dne 31. 10. 2017 bylo v Úředním věstníku Evropské unie ${ }^{1}$ publikováno nařízení Rady (EU) 2017/1939 ze dne 12. ř́ijna 2017, kterým se provádí posílená spolupráce za účelem zř́zení Úřadu evropského veřejného žalobce (dále jen „,nařízení o EPPO“). ${ }^{2}$ Česká republika byla v „první vlně“ 16 států, které oznámily dne 3. 4. 2017, že chtějí navázat posílenou spolupráci v této oblasti. Zapojením České republiky do projektu zř́zení a následného fungování Úřadu evropského veřejného žalobce (dále jen „EPPO“) tak vyvstala potřeba připravit náš právní řád na to, aby předmětné nařízení mohlo být pokud možno bez větších problémů aplikováno. Tento příspěvek má za cíl

\footnotetext{
* Autor je náměstkem nejvyššího státního zástupce na Nejvyšším státním zastupitelství.

1 Dostupné na: https://eur-lex.europa.eu/legal-content/CS/TXT/PDF/?uri=CELEX:32017R1939\&from=CS.

2 Pro zájemce o podrobnější informace o př́ípravě a legislativním procesu směřujícímu k přijetí nařízení o EPPO lze odkázat např. na ONDREJOVÁ, A. Európský prokurátor. Komentár k nariadeniu Rady Európskej únie, Bratislava: Wolters Kluwer, 2017, s. 15-74
} 
postihnout, zdůraznit a vysvětlit alespoň základní a nejdůležitější změny, které adaptace českého právního řádu přináší, resp. je předpokládáno, že přinese. ${ }^{3}$

Př́ípravy př́slušných změn se ujalo Ministerstvo spravedlnosti, do jehož gesce tato oblast právní úpravy spadá. Lze jistě ocenit, že po celou dobu př́ípravy adaptační právní úpravy probíhaly intenzivní konzultace s Nejvyšším státním zastupitelstvím, popř. zástupci vrchních státních zastupitelství, a to především ve formě jednání společné pracovní skupiny ve dnech 7. 11. 2017 a 16. 1. 2018 a dále průběžně nad jednotlivými oblastmi změn právní úpravy. Pracovní skupina byla postavena před nesnadný úkol, a to nalézt co možná nejvhodnější řššní změn právní úpravy, a to za situace, kdy zejména:

1. Zřízením EPPO se zcela nově dostává do trestního řízení v pozici jednoho z orgánů činných v trestním řízení subjekt (úřad, resp. osoby u něj činné) nikoliv vnitrostátní, ale Evropské unie. Toto však za situace, kdy nadále v trestním rrízení bude postupováno podle českých trestně právních předpisů (zejména trestního řádu), pokud nařízení o EPPO nestanoví jinak (čl. 5 odst. 3). Není tedy vytvořena úplná úroveň „,evropského“ trestního práva, tedy evropské právo trestní hmotné (evropský trestní zákoník) a procesní (evropský trestní řád), včetně úplné evropské úrovně orgánů činných v trestním řízení, tedy evropské policie, evropského orgánu veřejné žaloby (tento se v podobě EPPO nyní konstituuje) a evropských soudů. I ve věcech spadajících do př́slušnosti EPPO tak bude nadále činná police a soudy vnitrostátní.

2. Nebyly známy, popř́padě teprve v průběhu přípravy právní úpravy byly ze strany Evropské komise upřesňovány, informace zejména k statusovým a personálním otázkám evropských žalobců a evropských pověřených žalobců. Toto kladlo určité větší nároky na přeformulace, případně doplňování návrhu právní úpravy v průběhu přípravy a projednávání před jejím předložením do Poslanecké sněmovny Parlamentu České republiky.

3. Některá důležitá personální rozhodnutí, zejména o počtu a rozdělení věcné a místní př́slušnosti (dislokaci ${ }^{4}$ ) evropských pověřených žalobců (čl. 13 odst. 2 nařízení o EPPO) jsou vázána na schválení evropského nejvyššího žalobce, který však oproti původním plánům nebyl dosud ${ }^{5}$ Evropským parlamentem a Radou jmenován (čl. 14 odst. 1 nařízení o EPPO).

4. Nařízení o EPPO předpokládá řešení řady praktických otázek fungování EPPO v jednacím řádu EPPO. Jde např. o pokyny pro převedení rozhodovacích pravomocí stálé komory na dohlížejícího evropského žalobce, je-li škoda nižší než 100000 EUR

3 Dále v textu rozebíraný návrh zákona, kterým se mění zákon č. 283/1993 Sb., o státním zastupitelství, ve znění pozdějších předpisů, zákon č. 141/1961 Sb., o trestním řízení soudním (trestní rád), ve znění pozdějších předpisů, zákon č. 40/2009 Sb., trestní zákoník, ve znění pozdějších předpisů, a některé další zákony (sněmovní tisk č. 337, VIII. volební období), obsahuje i implementaci směrnice Evropského parlamentu a Rady (EU) 2017/1371 ze dne 5. července 2017 o boji vedeném trestněprávní cestou proti podvodům poškozujícím nebo ohrožujícím finanční zájmy Unie, s ohledem na vymezení tématu tohoto př́spěvku se této části navrhovaných změn právní úpravy věnovat nebudu.

4 Nařízení hovoří pouze o věcné a místní př́islušnosti mezi evropskými pověřenými žalobci uvnitř každého členského státu, což samozřejmě není to samé, co dislokace, ale nepochybně je zde nezbytná praktická souvislost. Zde návaznost na nově navrhovaný § 34b odst. 2 zákona o státním zastupitelství, ke kterému viz dále.

5 Tento článek je zpracován ke stavu ke dni 22. 8. 2019. 
(čl. 10 odst. 7), přezkum rozhodnutí evropských pověřených žalobců evropským žalobcem (čl. 12 odst. 4, bod 30 recitálu nařízení o EPPO) nebo zaznamenávání a ověřování informací poskytnutých Úřadu členskými státy či orgány, institucemi a jinými subjekty EU (čl. 24 odst. 6 nařízení o EPPO). Jelikož jednací ŕád EPPO nebyl dosud zpracován a jeho schválení je v kompetenci kolegia (čl. 21 odst. 2 nařízení o EPPO), ${ }^{6}$ které též dosud nebylo ustaveno, bylo i v tomto ohledu třeba připravovanou adaptační právní úpravu formulovat.

5. Navrhovaná právní úprava se musela soustředit (to je samotnou úlohou adaptační právní úpravy) na vytvoření podmínek fungování EPPO na území České republiky. Česká právní úprava nemůže řešit určité výkladové problémy samotného nařízení o EPPO nebo ukládat EPPO právní povinností, které by překračovaly její adaptační povahu a zasahovaly nad rámec nařízení o EPPO do činnosti EPPO. Zajištění efektivního fungování EPPO je primárně na samotném EPPO.

Práce na adaptační právní úpravě vyvrcholila zpracováním návrhu zákona, kterým se mění zákon č. 283/1993 Sb., o státním zastupitelství, ve znění pozdějších předpisů, zákon č. 141/1961 Sb., o trestním řízení soudním (trestní řád), ve znění pozdějších předpisů, zákon č. 40/2009 Sb., trestní zákoník, ve znění pozdějších předpisů, a některé další zákony, a který byl Vládou České republiky předložen Poslanecké sněmovně Parlamentu České republiky dne 20. 11. 2018 a je projednáván jako sněmovní tisk č. 337. Aktuálně je stav projednávání předmětného návrhu zákona takový, že dne 30. 1.2019 proběhlo první čtení a následně návrh projednal ústavně právní výbor, jako výbor garanční, a svým usnesením ze dne 10. 4. 2019 doporučil schválení návrhu a současně navrhl některé pozměňovací návrhy (viz sněmovní tisk č. 337/3).

Výše uvedené tak poněkud znesnadňuje zpracování tohoto př́spěvku, nebot' nelze vyloučit, že návrh adaptační právní úpravy obsažený ve sněmovním tisku č. 337 bude schválen $s$ určitými změnami proti předloženému textu (toto naznačují již ústavně právním výborem přijaté pozměňovací návrhy - viz výše). Dále budu vycházet ze stávajícího stavu navrhované právní úpravy, a to textu obsaženému v již citovaném sněmovním tisku č. 337.

\section{SOULAD PU゚SOBENÍ EPPO V ČESKÉ REPUBLICE S JEJÍM ÚSTAVNÍM POŘÁDKEM}

Jednou z klíčových otázek na počátku připravované adaptační právní úpravy bylo posouzení, zda samotné fungování EPPO v České republice je v souladu s jejím ústavním pořádkem.

Podle čl. 80 Ústavy České republiky je to státní zastupitelství, které zastupuje veřejnou žalobu v trestním řízení a vykonává i další úkoly, stanoví-li tak zákon. Tímto

6 Na jaře 2019 byl Evropskou komisí zpracován dokument „PREPARATORY DOCUMENT CONTAINING POSSIBLE BUILDING BLOCKS FOR THE INTERNAL RULES OF PROCEDURE OF THE EUROPEAN PUBLIC PROSECUTOR'S OFFICE“ (není veřejně dostupný), který byl předložen k projednání expertní skupině zřízené podle čl. 20 odst. 4 nařízení o EPPO. K tomuto dokumentu byla vznesena řada připomínek na jednání expertní skupiny ve dnech 27. a 28. 5. 2019, přičemž další osud př́ípravných prací není znám. Blíže se tímto s ohledem na vymezené téma př́spěvku nebudu zabývat. 
ustanovením je tak na ústavní úrovni vymezen hlavní úkol státního zastupitelství, který nemůže být státnímu zastupitelství odňat a kterým je zastupování veřejné žaloby, ale i další úkoly, které následně stanoví (stanovil) zákon.

Souladem s ústavním pořádkem se zabývala i důvodová zpráva k předmětnému návrhu zákona: „Jak uvádi komentářová literatura, primárním - objektivně ústavním smyslem existence ústavního zakotvení státního zastupitelství je jeho žretelné oddělení od moci soudní (v úzkém smyslu). Dochází k institucionálnímu oddělení procesních funkci př́pravy a podání obžaloby a rozhodování o vině a trestu mezi různé procesni subjekty. Význam odděleni státního zastupitelství a soudů se projevuje jako institucionální záruka i při hodnoceni dodržení subjektivního práva na spravedlivý proces. Z uvádèného článku Ústavy tak plyne pro zákonodárce povinnost zř́dit zákonem státní zastupitelství, jehož hlavní, nikoli však výlučnou, rolí bude zastupování veřejné žaloby $v$ trestním řizení. Z tohoto článku ale neplyne výlučnost státního zastupitelství jakožto jediného orgánu, který může veřejnou žalobu v trestním ř́zení zastupovat; státní zastupitelství v tomto směru nemá na zastupování veřejné žaloby v trestním řzení monopol. Ostatně $i$ v nedávné minulosti bylo zvažováno prolomeni dosavadni exkluzivity státního zastupitelstvi pri zastupováni veřejné žaloby v trestním ř́zení zavedením institutu soukromé žaloby (viz věcný záměr zákona o trestním řizení soudním, schválený usnesením vlády č. 996 ze dne 20. srpna 2008). Připadem, kdy je konkurenčně zavedena kompetence k zastupováni veřejné žaloby v trestním ř́zení, je i nařizení předvídané čl. 86 SFEU, který je právním základem pro zř́zení Úřadu evropského veřejného žalobce jakožto evropského orgánu př́slušného ,k vyšetřováni a stíhání pachateli̊ a spolupachatelu trestných činů poškozujících nebo ohrožujících finanční zájmy Unie ... a jejich předvádění před soud', který ,před př́slušnými soudy členských států vykonává v souvislosti s těmito trestnými činy úlohu veřejného žalobce " (viz čl. 86 odst. 2 SFEU)."7

Byt' by bylo možné vznášet pochybnosti o argumentaci institutem soukromé (i subsidiární) žaloby, který nepochybně odlišným institutem od veřejné žaloby, o které hovoří čl. 80 Ústavy České republiky, ale jako podstatné je třeba hodnotit i to, že evropský žalobce a evropský pověřený žalobce, kteří budou ,za Českou republiku“ působit u EPPO a budou zpracovávat „naše národní“ trestní věci v působnosti EPPO musí být aktivními státními zástupci (tzv. princip „double hat“). Z tohoto vychází i navrhovaná právní úprava nového $§ 34$ b zákona o státním zastupitelství ${ }^{8}$ a doplnění $§ 12$ odst. 5 trestního řádu 9 (podrobněji viz níže).

Současně se jedná o zřizení instituce, jejíž vnik předvídá Smlouva o fungování Evropské unie ${ }^{10}$ ve svém čl. 86 a Česká republika tuto smlouvu ratifikovala. ${ }^{11}$

Mám tedy za to, že navrhovaná právní úprava z ústavního hlediska obstojí a fungování EPPO v České republice z tohoto pohledu nic nebrání.

\footnotetext{
Sněmovní tisk č. 337, VIII. volební období, s. 24.

8 Zákon č. 283/1993 Sb., o státním zastupitelství, ve znění pozdějších předpisů.

9 Zákon č. 141/1961 Sb., o trestním řízení soudním (trestní řád), ve znění pozdějších předpisů.

10 Dostupné na: https://eur-lex.europa.eu/legal-content/CS/TXT/?uri=celex\%3A12012E\%2FTXT.

11 K tomuto viz též i čl. 288 Smlouvy o fungování Evropské unie a rozsudek Soudního dvora Costa v. E.N.E.L., věc 6/64..
} 


\section{EPPO A ZÁKON O STÁTNÍM ZASTUPITELSTVÍ}

Návrh adaptační právní úpravy se musel nejprve vypořádat se zcela nezbytnými změnami zákona o státním zastupitelství.

\subsection{DOPLNĚNÍ VYMEZENÍ OBLASTI ÚPRAVY ZÁKONA O STÁTNÍM ZASTUPITELSTVÍ A UPŘESNĚNÍ TRESTNÍ PŮSOBNOSTI STÁTNÍHO ZASTUPITELSTVÍ}

Navrhovanou právní úpravou se doplňuje $§ 1$ odst. 2 zákona o státním zastupitelství, a to spolu s odkazem na nařízení o EPPO (byt' vyjádřeno opisem a odkazem ve vkládané poznámce pod čarou) o tři okruhy právní úpravy, a to o postavení státních zástupců působících u EPPO, o poskytování informací a součinnosti mezi státním zastupitelstvím a EPPO. Jedná se o legislativně technický požadavek vyplývající z čl. 48 odst. 2 Legislativních pravidel vlády. ${ }^{12}$

Na výše uvedené navazuje i změna $\mathrm{v} \S 4$ odst. 1 písm. a) zákona o státním zastupitelství, která stanoví, že státní zastupitelství v rozsahu, za podmínek a způsobem stanoveným zákonem je orgánem veřejné žaloby v trestním řízení a plní další úkoly vyplývající z trestního řádu. Nově se navrhuje vložení výjimky právě pro případy, kdy nařízení o EPPO stanoví jinak. Touto výjimkou se tak redukuje rozsah působnosti státního zastupitelství v rámci trestního řízení, nebot' některá trestní ř́zení budou z jeho pravomoci zcela vyjmuta a v některých trestních rrízeních bude výkon pravomoci státního zastupitelství závislý na rozhodnutí EPPO (zdržení se výkonu své pravomoci podle čl. 25 odst. 3 nařízení o EPPO, postoupení a předání řízení vnitrostátním orgánům podle čl. 34 nařízení o EPPO nebo uplatnění evokačního práva podle čl. 27 nařízení o EPPO). Byt' by se dalo dovozovat, že se jedná o právní úpravu nadbytečnou a plně postačuje čl. 5 odst. 3 nařízení o EPPO, tak ale mám za to, že jde o velmi vhodné upřesnění rozsahu trestní působnosti vymezené $\mathrm{v}$ zákoně o státním zastupitelství a poskytnutí jistoty právní úpravy. Tímto doplněním změna zákona reaguje na čl. 22, čl. 25 odst. 1, čl. 27 odst. 2 a 5 a čl. 34 odst. 1 a 2 nařízení o EPPO.

Zákon v návaznosti na čl. 25 odst. 6 nařízení o EPPO řeší i situace, kdy dojde k nesouladu, zda věc spadá do působnosti státního zastupitelství nebo EPPO. Citovaný článek nařízení svěřuje členskému státu určení, který vnitrostátní orgán bude rozhodovat spory o př́slušnost. Ustanovení § $34 \mathrm{~g}$ zákona o státním zastupitelství takovým orgánem určuje Nejvyšší státní zastupitelství. Tato volba je logická, nebot' jde o spory o př́ślušnost mezi orgány veřejné žaloby.

\subsection{POSTAVENÍ STÁTNÍCH ZÁSTUPCŮ PŮSOBÍCÍCH U EPPO}

EPPO bude působit na centrální a decentralizované úrovni. Na centrální úrovni bude (obligatorně, jelikož se Česká republika zapojila do projektu EPPO) působit evropský žalobce a může (pokud se tak někdy stane) působit evropský nejvyšší

12 Dostupné na: https://www.vlada.cz/assets/jednani-vlady/legislativni-pravidla/LEGISLATIVNI-PRAVIDLA -VLADY_platne-od-1-2-2018.pdf. 
žalobce. Na decentralizované úrovni (vnitrostátně v každém státě, který se zapojil nebo i v budoucnu zapojí do projektu EPPO) budou působit evropští pověření žalobci, a to podle čl. 13 odst. 2 nařízení o EPPO závazně nejméně dva. Evropských pověřených žalobců může $v$ jednotlivém státě působit i více, ale toto musí být schváleno evropským nejvyšším žalobcem po konzultacích s příslušnými orgány členského státu.

Evropský žalobce a evropský pověřený žalobce, kteří budou „za Českou republiku“ působit u EPPO a budou zpracovávat „naše národní“ trestní věci v působnosti EPPO musí být aktivními státními zástupci (tzv. princip „,double hat“). U evropského nejvyššího žalobce toto zcela neplatí, nebot' mimo státní zástupce navrhovaná právní úprava změnou § 70a zákona o soudech a soudcích ${ }^{13}$ umožňuje, aby se evropským nejvyšším žalobcem stal i soudce. $Z$ povahy funkce evropského žalobce i evropského pověřeného žalobce je zřejmé, že půjde pouze o státní zástupce. Byt' nařízení o EPPO dává možnost pro evropské žalobce a evropské pověřené žalobce členství v soudních orgánech, toto se ale vtahuje na členské státy, u kterých v rámci trestního řízení působí vyšetřující soudci. Jak správně uvádí i důvodová zpráva: ${ }^{14}$ „Toto stanovisko podporuje i dokument Komise k výběru evropských žalobců, dle něhožje žádoucí, aby kandidáti na evropského žalobce měli rozsáhlé zkušenosti jako státní zástupci, a to včetně praktických zkušeností $s$ vyšetřováním a stíháním př́padů závažné hospodářské kriminality a korupce stejně jako s mezinárodní spoluprací v trestnich věcech, zkušenosti s organizaci a koordinací činnosti jiných státnich zástupcủ či zkušenosti s přshraničním vyšetřováním. Pokyny Komise sice nejsou pro členské státy závazné, ale vyberou-li členské státy kandidáty, kteři uvedeným charakteristikám nevyhovují, nelze vyloučit, že členský stát bude požádán o nahrazení takových kandidátù, což by značně zkomplikovalo výběrové ř́zení na tuto funkci.“

K výběru osob na funkční místa evropských žalobců a evropských pověřených žalobců je třeba odkázat na usnesení Vlády České republiky ze dne 31. 10. 2018, č. 702, kterým vzala na vědomí způsob výběru evropských žalobců a evropských pověřených žalobců za Českou republiku podle nařízení o EPPO a schválila pravidla pro výběr kandidátů na funkci evropského žalobce. $Z$ tohoto usnesení a podkladových materiálư ${ }^{15}$ vyplývá, že pravidla pro výběr evropských žalobců byla schválena př́mo vládou a zpracování pravidel pro výběr kandidátů na evropské pověřené žalobce je ponecháno na nejvyšším státním zástupci, a to na základě transparentního výběrového rrízení, který navrhne vybrané kandidáty ministru spravedlnosti k nominaci.

V návaznosti na shora uvedené bylo třeba na vnitrostátní úrovni právně upravit postavení státních zástupců, kteří budou činní jako evropští pověření žalobci, evropští žalobci a evropský nejvyšší žalobce. Analýzou stávajících institutů zákona o státním zastupitelství bylo zjištěno, že tyto na požadované případy nejsou beze zbytku použitelné. $Z$ tohoto důvodu návrh zákona přichází v navrhovaném § $34 \mathrm{~b}$ se zcela novým institutem dočasného přidělení státního zástupce $\mathbf{k}$ EPPO. Tento institut vychází z toho, že k dočasnému přidělení státního zástupce dochází ex lege, a to dnem, kdy vznikla

13 Zákon č. 6/2002 Sb., o soudech, soudcích, přísedících a státní správě soudů a o změně některých dalších zákonů (zákon o soudech a soudcích), ve znění pozdějších předpisů.

14 Sněmovní tisk č. 337, VIII. volební období, s. 21-22.

15 Dostupné na: https://apps.odok.cz/veklep-detail?pid=KORNAYUM5N7T. 
státnímu zástupci funkce evropského nejvyššího žalobce, evropského žalobce a evropského pověřeného žalobce. Pokud $v$ případech předvídaných nařízením o EPPO dojde k prodloužení funkčního období, zůstane i dočasné přidělení v platnosti. ${ }^{16}$ Během dočasného přidělení osoba zůstává státním zástupcem, ale výkon jeho vlastní činnosti a úkonů je sistován. Z tohoto je možná výjimka u evropských pověřených žalobců, kdy předmětný $\S 34 b$ umožňuje podle čl. 13 odst. 3 nařízení o EPPO, aby souběžně s výkonem této funkce vykonávali i vnitrostátně funkci státních zástupců (částečné úvazky); toto však není z podstaty věci možné ani u evropského žalobce, ani u evropského nejvyššího žalobce.

Zatímco dočasné přidělení státního zástupce k EPPO nastává ex lege, tak podle navrhovaného $§ 34$ b odst. 2 stanoví ministr spravedlnosti po projednání s nejvyšším státním zástupcem a se souhlasem státního zástupce jmenovaného do funkce evropského pověřeného žalobce určité státní zastupitelství jako místo výkonu jeho funkce. Toto stanovení místa výkonu funkce bude muset navazovat na projednání rozdělení věcné a místní př́slušnosti mezi evropského pověřenými žalobci s evropským nejvyšším žalobce, jak je stanoví čl. 13 odst. 2 nařízení o EPPO. V rámci přípravných prací se pracovně počítalo s působením evropských pověřených žalobců při vrchních státních zastupitelstvích.

V návaznosti na stanovení místa výkonu funkce evropského veřejného žalobce upravuje nově navrhovaný § 34c zákona o státním zastupitelství bližší otázky tohoto působení. Jednak se státní zastupitelství, které bylo stanoveno jako místo výkonu funkce státního zástupce, považuje za státní zastupitelství, u kterého je evropský pověřený Žalobce činný, což navazuje na změny právní úpravy trestního řádu (viz změny $§ 146 \mathrm{a}$ a $§ 158$ e trestního řádu uvedené dále). A uvedené ustanovení dále naplňuje čl. 96 odst. 6 nařízení o EPPO, které mimo jiné stanoví, že: „Přislušné vnitrostátní orgány poskytnou evropským pověřným žalobcům především zdroje a zařizení nezbytná $k$ výkonu jejich funkce podle tohoto nařizení a zajistí jejich plnou integraci do vnitrostátních útvarů pověrených trestním stíháním“ a též že „Odpovědnost za všeobecné pracovní podmínky a pracovní prostředi evropských pověřnených žalobců nesou př́slušné vnitrostátni justiční orgány. "Vztah vedoucího státního zástupce k evropským pověřeným žalobcům velmi dobře shrnuje důvodová zpráva k návrhu zákona: ${ }^{17}$ „Vedouci státní zástupce, který bude stát v čele státního zastupitelství, které bylo stanoveno jako místo výkonu funkce evropského pověreného žalobce, je v rozsahu, v jakém to nařizení, kterým se provádí posílená spolupráce za účelem zř́zení Úradu evropského veřejného žalobce, umožňuje, evropskému pověrenému žalobci nadřizen a vykonává vůči němu svá řídici a kontrolní oprávnění. Tato oprávnění jsou spíše administrativní povahy, kdy vedouci státní zástupce může kontrolovat např. zacházení se svěreným majetkem, který poskytne evropskému pověrenému žalobci členský stát (srov. čl. 96 odst. 6 nařizení) nebo bezpečnost práce s ohledem na to, že členské státy jsou odpovědné za všeobecné pracovní podmínky a pracovni prostředi evropských pověrených žalobců (srov. čl. 96

16 Evropský nejvyšší žalobce - funkční období 7 let bez možnosti prodloužení (čl. 14 odst. 1 nařízení o EPPO), evropský žalobce - funkční období 6 let s možností prodloužení o 3 roky (čl. 16 odst. 3 nařízení o EPPO), evropský pověřený žalobce - obnovitelné pětileté funkční období (čl. 17 odst. 1 nařízení o EPPO).

17 Sněmovní tisk č. 337, VIII. volební období, s. 37. 
odst. 6 nařizeni), zásadně se nemohou týkat vlastniho postupu v konkrétní věci (v rámci dohledu, v rámci kontroly skončené věci apod.). Toto ustanovení, resp. adaptované nařizeni tak modifikuje obsah správy prováděné vedoucimi státnimi zástupci či jejich náměstky (\$13a a násl. zákona o státním zastupitelství)." Stát tak musí zajistit evropskému pověřenému žalobci pracovní prostř̌edí ve formě kanceláře, výpočetní techniky, ale i administrativního personálu apod.

Ustanovení § 34d zákona o státním zastupitelství pak obecně shrnuje, že: „Evropský nejvyšší žalobce, evropský žalobce a evropský pověrený žalobce mají v rozsahu, vjakém to nařizeni o zřizení Úr̆́adu evropského veřejného žalobce umožňuje, stejná oprávnění a povinnosti, jaké jsou stanoveny právními predpisy státnímu zástupci." Tato úprava je pak pro trestní rízení konkretizována ve změně $§ 12$ odst. 5 trestního řádu (viz dále). Současně je však tato úprava potřebná i v zákoně o státním zastupitelství, nebot' se jedná o jakési ustanovení „preventivni“. Jelikož nevíme, jak bude vypadat interní úprava chodu EPPO (jednací řád EPPO), je jednoznačné srovnání postavení evropského nejvyššího žalobce, evropského žalobce a evropského pověřeného žalobce na obecné úrovni s právy a povinnosti státních zástupce důležité.

Státní zástupci působící v rámci EPPO (evropští pověření žalobci, evropští žalobci nebo evropský nejvyšší žalobce) budou nadále i státními zástupci České republiky a je tak třeba řešit i problematiku, pokud stát vůči těmto státním zástupcům hodlá stát uplatnit disciplinární odpovědnost, jejíž součástí je jako kárné opatření i možnost odvolání z funkce, a dále rozhodovat o nezpůsobilosti státního zástupce $\mathrm{k}$ výkonu funkce nebo dočasně takového státního zástupce zprostit výkonu funkce. $Z$ tohoto důvodu se jeví třeba především novelizace $\S 27$ zákona o státním zastupitelství, a to tak, že tito státní zástupci jsou odpovědní za kárné provinění v případech, ve kterých to nařízení o zřízení Úřadu evropského veřejného žalobce umožňuje (ustanovení není doplněno o evropského nejvyššího žalobce). Tato změna právní úpravy navazuje na čl. 17 odst. 4 nařízení o EPPO, který stanoví, že: „Pokud členský stát rozhodne, že vnitrostátniho žalobce, který byl jmenován do funkce evropského pověreného žalobce, odvolá nebo mu uloži disciplinárni opatření z di̊vodů, které nesouvisí s jeho povinnostmi podle tohoto nařizení, informuje evropského nejvyššího žalobce před tím, než daný krok učiní. Členský stát nesmi evropského pověreného žalobce odvolat ani mu uložit disciplinární opatření $z$ di̊vodi souvisejicich s jeho povinnostmi podle tohoto nařizeni bez souhlasu evropského nejvyššiho žalobce. Pokud evropský nejvyšši žalobce nesouhlasí, může dotčený členský stát požádat kolegium o prezekum této záležitosti. “Tedy samo nařízení o EPPO počítá s možností přesahu disciplinární (kárné) odpovědnosti. Z uvedeného vyplývá, že evropského žalobce je možné disciplinárně (kárně) postihovat pouze pro jednání, které nesouvisí s jeho působením jako evropského žalobce (prakticky by mohlo jít např. o porušení některých z povinností stanovených $\mathrm{v} \S 24$ zákona o státním zastupitelství v soukromém životě), pro jednání při výkonu funkce evropského žalobce podléhá tato osoba disciplinární odpovědnosti podle nařízení, a tedy rozhodování kolegia (viz čl. 17 odst. 3 nařízení o EPPO). U evropských pověřených žalobců platí to samé, co u evropského žalobce, ale současně evropský pověřený žalobce může současně působit i jako vnitrostátní státní zástupce a je tak třeba mít vůči němu standardní nástroje disciplinární odpovědnosti (v těchto případech platí povinnost informovat evropského nejvyššího 
žalobce). Jak ale vyplývá ze shora uvedené citace nařízení o EPPO lze se souhlasem evropského nejvyššího žalobce disciplinárně postihovat evropského pověřeného žalobce i pro jednání podle nařízení o EPPO. O tomto hovoří i bod 46 recitálu nařízení o EPPO: „Kolegium by mělo být odpovědné za disciplinárni ř́zeni týkajicí se evropských pověrených žalobců jednajicich na základě tohoto nařizení. Jelikož evropští pověrení žalobci zůstávaji aktivnimi členy státních zastupitelství nebo soudních orgánů členských států a mohou rovněž vykonávat funkci vnitrostátnich žalobcü, mohou se na ně vztahovat vnitrostátni disciplinární ustanoveni z důvodù, které nesouvisí s tímto nařizením. Evropský nejvyšši žalobce by však s ohledem na svou odpovědnost za ř́zení Úřadu a za účelem ochrany jeho integrity a nezávislosti mèl v takových prípadech být informován o prrípadném propuštěni nebo jakémkoli disciplinárním opatření."

Jak uvádí důvodová zpráva $\mathrm{k}$ citovanému návrhu zákona: ${ }^{18}$ „V prípadè evropským pověrených žalobců (nikoli však evropských žalobců) nařizeni teoreticky připouští, že tito mohou být kárně žalováni i z důvodů souvisejícich s jeho povinnostmi podle nařizení o zř́zení Úruadu, v tom př́padè nicméně musí členský stát pro možné odvolání nebo uložení disciplinárního opatření ziskat souhlas evropského nejvyššiho žalobce; pokud evropský nejvyšší žalobce s odvoláním nebo uložením disciplinárního opatření nesouhlasí, může dotčený členský stát požádat kolegium o přezkum této záležitosti. Pro př́pady, pokud by byla podána kárná žaloba na evropského pověreného žalobce, jejímž předmètem by bylo kárné proviněni spočivajicí v jednání souvisejicím s povinnostmi podle nařizení o zř́zení Úřadu, pak uvedené postupy před uložením kárného opatření v kárném ř́zení zajistí kárný senát."

Kárnými žalobci budou ministr spravedlnosti a nejvyšší státní zástupce, jako univerzální kární žalobci podle $\S 8$ odst. 5 písm. a) zákona č. 7/2002 Sb., o řízení ve věcech soudců, státních zástupců a soudních exekutorů, ve znění pozdějších přepisů, a nově bylo toto ustanovení doplněno o písmeno e), kdy kárným žalobcem vǔči evropskému pověřenému žalobci stanoví nově i vedoucího státního zástupce, který stojí v čele státního zastupitelství, které bylo stanoveno jako místo výkonu funkce státního zástupce jmenovaného do funkce evropského pověřeného žalobce, a to právě proti tomuto státnímu zástupci (evropskému pověřenému žalobci). Současně se v návaznosti na již citovaný čl. 17 odst. 4 nařízení o EPPO doplňuje i informační povinnosti v kárném ř́zzení, a to o podání návrhu na zahájení kárného řízení, o konání ústního jednání a bude zasíláno i písemné vyhotovení rozhodnutí (doplnění § 12, § 16 a § 20 zákona č. 7/2002 Sb.).

Co bylo uvedeno $\mathrm{k}$ disciplinární odpovědnosti, platí přiměřeně i pro rozhodování o nezpůsobilosti státního zástupce $\mathrm{k}$ výkonu funkce nebo o dočasném zproštění státního zástupce výkonu funkce. Nařízení o EPPO sice o dočasném zproštění výkonu funkce státního zástupce výslovně nehovoří, ale byt' dočasně se jedná o zásadní omezení výkonu funkce státního zástupce a je třeba postupovat ve vztahu k EPPO obdobně. V tomto smyslu návrh zákona provádí i př́íslušné novelizace $§ 22$ a $§ 26$ zákona o státním zastupitelství.

18 Sněmovní tisk č. 337, VIII. volební období, s. 49. 


\subsection{POSKYTOVÁNÍ INFORMACÍ A SOUČINNOSTI MEZI STÁTNÍM ZASTUPITELSTVÍM A EPPO}

Povinnost zajistit poskytování informací vnitrostátními orgány z jejich databází (myšleno tím v širokém slova smyslu, tedy informačních systémů či jiných evidencí) pro účely EPPO stanoví čl. 43 odst. 1 nařízení o EPPO, a to za stejných podmínek, jaké se v podobných př́ípadech uplatňují podle vnitrostátního práva. Tedy evropští pověření žalobci musí mít stejný přístup k informacím (stejný standard př́stupu) jako státní zástupci. Ustanovení § 12i odst. 3 zákona o státním zastupitelství dává právní základ pro existenci Centrální evidence stíhaných osob, jakožto informačního systému spravovaného Nejvyšším státním zastupitelstvím, a dále též upravuje jeho účel a základní podmínky jeho fungování, tedy formu a rozsah shromažd’ovaných údajů a zmocnění $\mathrm{k}$ jeho užití. Zatímco pro využívání Centrální evidence stíhaných osob nebylo změny třeba, nebot' rozhodné osoby činné u EPPO budou mít postavení orgánu činného v trestním řízení (viz níže ke změnám $§ 12$ odst. 5 trestního řádu) a tyto orgány mají již nyní príistup na základě zákonného zmocnění z § 12 i odst. 4 zákona o státním zastupitelství, tak ale naopak bylo třeba stanovit, že i EPPO má do Centrální evidence stíhaných osob údaje poskytovat. Tato právní úprava dává smysl, nebot' jinak by se Centrální evidence stíhaných osob stala neúplnou, což by snízilo její obsahovou validitu a využitelnost nejen pro vnitrostátní orgány činné v trestním řízení, ale i pro EPPO samotný. Bližší postup realizace poskytování údajů ze strany EPPO do Centrální evidence stíhaných osob není třeba zákonem upravovat, nebot' se bude jednat o technické řešení.

Státní zastupitelství v rámci své činnosti zpracovává řadu údajů (včetně údajů osobních). Zpracování je prováděno $\mathrm{v}$ rámci systému spisové služby a v informačních systémech, které státní zastupitelství uživá (např. ISYZ). Současně ale státní zastupitelství potřebuje využívat i údaje z jiných zdrojů, než ze svých vlastních, a to na základě principu sdílení dat mezi orgány veřejné moci. Obdobně tomu bude i u EPPO, prričemž jak již uvedeno výše, evropští pověření žalobci musí mít stejný př́stup k informacím jako státní zástupci. Do § 12j zákona o státním zastupitelství tak byl vložen právní titul pro získávání údajů ze základního registru obyvatel (viz zákon č. 111/2009 Sb., o základních registrech, ve znění pozdějších předpisů, zejména $§ 16$ až § 23), z agendového informačního systému evidence obyvatel (viz zákon č. 133/2000 Sb., o evidenci obyvatel a rodných číslech a o změně některých zákonů, zejména jeho § 3 ) a $\mathrm{z}$ agendového informačního systému cizinců (viz zákon č. 329/1999 Sb., o pobytu cizinců na území České republiky a o změně některých zákonů, zejména $§ 158$ až § 160a). Oproti požadavku uvedenému v čl. 43 odst. 1 nařízení o EPPO na zajištění př́stupu pro evropské pověrené žalobce, tak navrhovaná právní úprava rozšiřuje př́istup na celý EPPO (přístup bude třeba nejen pro evropského žalobce a evropského pověřeného žalobce, ale i pro další odborný personál). Jedná se tak o obdobný prístup jako na vnitrostátní úrovni, kdy též př́stup do shora uvedených informačních systémů není možný pouze pro státní zástupce, ale oprávněno je státní zastupitelství.

Výše uvedená konkrétní oprávnění pro EPPO jsou pak doplněna obecnější právní úpravou v § 34d odst. 2 a 3 zákona o státním zastupitelství. Odstavec 2 stanoví, že: „Ưrad evropského veřejného žalobce je pro výkon své pưsobnosti oprávněn získávat 
informace z rejstřikư, registrů, evidencí, databázi a seznamů ve stejném rozsahu a stejným způsobem, jako je získává státní zástupce pro účely trestního řizeni“", což je jak již uvedeno i u př́ípadů výše projevem adaptace čl. 43 odst. 1 nařízení o EPPO. A odstavec 3 vztahuje obdobně proces a rozsah poskytování informací v soustavě státního zastupitelství podle $\S 12 \mathrm{~g}$ odst. 1 a podle nově vkládaného odstavce 2 na vztah soustavy státního zastupitelství a EPPO, a to vzájemně.

Otazníky by mohla vyvolávat věta druhá odstavce 3 §34d, které stanoví, že: „Na oprávněni ministra spravedlnosti požádat Úřad evropského veřejného žalobce o informaci o stavu ř́zení ve věci, ve které je Úř́ad evropského veřejného žalobce činný, se $\S 13$ odst. 1 použije obdobně." Na jedné straně čl. 6 odst. 1 nařizení o EPPO zdůrazňuje nezávislost EPPO, nepřijímání pokynů, respektování nezávislosti a odmítání ovlivňování $\mathrm{v}$ jeho činnosti ze strany členských států, na druhé straně je třeba ale přisvědčit tomu, že stát by měl mít nárok na určité informace o trestním řízení v působnosti EPPO, protože se bude stále dotýkat tohoto konkrétního státu a může to mít vliv na jeho chod. Navržená právní úprava se tak jeví jako rozumný kompromis, kdy žádosti o informace jsou podřízeny již existujícímu § 13 odst. 1 zákona o státním zastupitelství, a pouze $\mathrm{v}$ tomto rozsahu by bylo možno informace požadovat a dále žádostí o informace se ani nedává pokyn, ani se EPPO nijak neovlivňuje a není tak dotčen již citovaný čl. 6 odst. 1 nařízení o EPPO.

Jako ustanovení mající informační povahu lze považovat i nový § 34e zákona o státním zastupitelství, které stanoví, že: „Státní zastupitelství je povinno neprodleně oznámit Úřadu evropského veřejného žalobce skutečnosti nasvědčujicí tomu, že byl spáchán trestný čin, u něhož by Úr̆ad evropského veřejného žalobce mohl vykonat svou pravomoc v souladu s čl. 22 a čl. 25 odst. 2 a 3 nařizení o zřizení Úřadu evropského veřejného žalobce." Toto ustanovení navazuje na čl. 24 odst. 1 nařízení o EPPO. S tímto ustanovení souvisí změna $\S 158$ odst. 1 trestního řádu, která stanoví policejnímu orgánu povinnost informovat státního zástupce o skutečnostech nasvědčujících tomu, že byl spáchán trestný čin, u něhož by EPPO mohl vykonat svou pravomoc v souladu s čl. 22 a čl. 25 odst. 2 a 3 nařízení o EPPO. Policejní orgán tedy nemůže činit předmětné oznámení EPPO samostatně, ale toto oprávnění podávat oznámení EPPO je koncentrováno do rukou státního zástupce, resp. státního zastupitelství. S ohledem na to, že podávání oznámení EPPO je činěno mimo rámec vnitrostátního trestního rízení je tento postup systematicky zařazen do zákona o státním zastupitelství.

Uvedené změny zákona o státním zastupitelství jsou též projevem požadavku na uplatňování zásady loajální spolupráce mezi vnitrostátními orgány a EPPO, jak vyplývá z čl. 5 odst. 6 a bodu 14 recitálu nařízení o EPPO.

\section{EPPO A TRESTNÍ ŘÁD}

Nařízení o EPPO není pouze právním předpisem organizační povahy (upravující otázky organizace, vnitřního chodu a personálního postavení osob činných u EPPO), ale obsahuje i ustanovení trestně procesního charakteru. Vztah nařízení o EPPO a vnitrostátní právní úpravy je definován v čl. 5 odst. 3, který stanoví, že: „Vy- 
šetřováni a trestni stíháni vedená jménem Úřadu se ř́dí tímto nařizením. Vnitrostátní právo se použije v rozsahu, ve kterém neni daná věc upravena tímto nařizením. Není-li $v$ tomto nařizení stanoveno jinak, je rozhodným vnitrostátním právem právo toho členského státu, jehož evropský pověrený žalobce daný prípad v souladu s čl. 13 odst. 1 projednává. Pokud se prípad řídí vnitrostátním právem i tímto nařizením, má toto nařizení přednost. “ Je tak stanovená důležitá, či přímo stěžejní, zásada přednosti užití nařízení o EPPO před vnitrostátní právní úpravou. Trestní rízení v působnosti EPPO tak bude vedeno podle trestního řádu České republiky, avšak tam, kde nařízení o EPPO stanoví jinak, užije se právě právní úprava stanovená v nařízení o EPPO.

V návaznosti na shora uvedené bylo při př́ípravě adaptační právní úpravy třeba vyřešit otázku, jak koncepčně $\mathrm{k}$ jejímu zpracování přistoupit. Do úvahy přicházelo řešení velmi podrobné právní úpravy detailně reagující a zohledňující jednotlivá ustanovení nařízení o EPPO a na toto navazující změny trestního řádu, kde by byly činěny odkazem na nařízení o EPPO výjimky a poukazováno na odlišný postup podle nařízení o EPPO. Toto řešení však bylo $\mathrm{v}$ rámci interních diskuzí pracovní skupiny odmítnuto $\mathrm{z}$ důvodu jeho nepřehlednosti, jeho komplikovanost a současně i s ohledem na zásadu, že adaptační právní úprava by měla připravit národní právní úpravu na aplikaci nařízení, ale nikoliv nařízení či jeho podstatné části do národní právní úpravy přepisovat.

Bylo tak zvoleno obecné řešení obsažené v $\S 12$ odst. 5 trestního řádu spočívající v rozšíření definice státního zástupce (jakožto orgánu činného v trestním řízení) tak, že státním zástupcem se rozumí i evropský pověřený žalobce, evropský žalobce a evropský nejvyšší žalobce ${ }^{19} \mathrm{v}$ rozsahu jejich působnosti stanovené nařízením o EPPO. Tato koncepce vychází z čl. 13 odst. 1 nařízení o EPPO, který stanoví ve stručnosti, že jsou to právě evropští pověření žalobci, kteří mají mít postavení žalobců ve stejném rozsahu jako vnitrostátních žalobců. Dále tato koncepce vychází též i z čl. 28 odst. 4 nařízení o EPPO, které dává tuto možnost i evropským žalobcům.

Standardní model by měl být ten, že evropský pověřený žalobce bude vést trestní řízení (vyšetřování a trestní stíhání ve smyslu používaném v nařízení o EPPO) sám, ale v př́ípadě České republiky pravděpodobněji využije možnost danou čl. 28 odst. 1 nařízení o EPPO a zapojí do trestního řízení policejní orgány v rozsahu obvyklém v trestních řízení vedených vnitrostátně. ${ }^{20}$ Evropský žalobce by měl primárně dohlížet na trestní řízení vedená evropskými pověřenými žalobci (viz čl. 12 odst. 1 nařízení o EPPO).

Při zohlednění východisek uvedených výše $\mathrm{v}$ části I. byla v trestním řádu dále identifikována místa, kde bylo nutné reagovat na vedení trestního řízení v působnosti EPPO. Současně a jak již bylo uvedeno výše, právě při př́pravě změn trestního řádu se nejvíce projevila nutnost adaptační právní úpravou nezasahovat do činnosti EPPO nad rámec

19 Byt' novelizace dává postavení státního zástupce i evropskému nejvyššímu žalobci, a důvodová zpráva na str. 22 a 23 toto odůvodňuje tím, že: „Vzhledem ke skutečnosti, že některé otázky nejsou adaptovaným nařizením řešeny a budou předmětem interni úpravy Úradu evropského veřejného žalobce (jeho jednacího rádu), je na mistě prizznat postavení státního zástupce i evropskému nejvyššimu žalobci, nebot' nelze vyloučit, že i ten bude na trestním ř́zeni participovat." Zde je třeba rozlišit jeho participaci na trestním řízení př́ímo vyplývající z nařízení o EPPO (např. jeho participaci na činnosti Stálých komor podle čl. 10 odst. 1 nařízení o EPPO, postup podle čl. 29 nebo podle $\S 34$ odst. 4 nařízení o EPPO) a participaci navazující na postup podle ustanovení trestního řádu (viz např. nové znění § 265r odst. 2 trestního řádu).

20 Podrobný rozbor toho, jak bude vypadat trestní íízení vedené ve věcech v působnosti EPPO, by překračoval vymezené témat tohoto př́spěvku, resp. by vydal na rozsáhlý př́ispěvek samostatný. 
nařízení o EPPO a současně se projevila i absence jednacího řádu EPPO. Zvoleno bylo takové řešení, že $\mathrm{v}$ těch případech, kdy nařízení o EPPO nic nestanoví (či stanoví jen velmi obecně) a současně je třeba, aby podle trestního řádu konala nadřízená složka v rámci EPPO nad evropským pověřeným žalobcem (potažmo, byt' výjimečně, i nad evropským žalobcem), tak navrhovaná právní úprava odkazuje na př́ślušný orgán EPPO. Zvolené řešení tak předpokládá, že to bude především jednací řád EPPO, ${ }^{21}$ který by měl uvedené otázky řešit, když současně našemu právnímu řádu nepř́sluší zasahovat do vnitřní činnosti EPPO tím, že by sám toto řešení nějakým způsobem předjímal.

Jedná se především o otázku určení instančního orgánu podle $§ 146$ odst. 2 trestního řádu. Nařízení o EPPO stanoví pouze v čl. 12 odst. 4, že: „Pokud vnitrostátní právo některého členského státu stanoví vnitřní přezkum některých úkonů v rámci vnitrostátní struktury státniho zastupitelství, spadá prezkum takových aktů evropského pověreného žalobce do pravomocí dohližejicího evropského žalobce v oblasti dohledu v souladu s jednacím ř́dem Úřadu, aniž je dotčena pravomoc stálé komory v oblasti dohledu a sledováni. " $Z$ tohoto ustanovení není zcela zřejmé, zda se jím má na mysli i instanční přezkum podle trestního řádu nebo spíše institut obdobný dohledu podle § $12 \mathrm{c}$ a násl. zákona o státním zastupitelství. Současně se toto ustanovení nařízení o EPPO vztahuje pouze na „akty“ (tedy i usnesení) evropského pověřeného žalobce a nikoliv na usnesení vydaná policejním orgánem na pokyn nebo se souhlasem evropského pověřeného žalobce nebo na usnesení evropského žalobce. Tyto př́ípady tak musela řešit adaptační právní úpravy právě odkazem na př́islušný orgán EPPO s tím, že se předpokládá bližší interní úprava v jednacím řádu EPPO.

Obdobně je postupováno a trestní rád byl doplněn i u zpětvzetí stížnosti podané evropským pověřeným žalobcem nebo evropským žalobcem podle $§ 144$ odst. 2 trestního řádu, u zpětvzetí odvolání podle $\S 250$ odst. 2 trestního řádu, v řízení u dovolání podle $\S 265$ d odst. 1 písm. b), $\S 265$ fodst. $1, \S 265 \mathrm{~g}$, $\$ 265$ h odst. 1 a $2, \S 265$ o odst. $2, \S 265$ p odst. 1 a $\S 265$ r odst. 1 písm. c) trestního rádu a u prošetřování podnětu ke stížnosti pro porušení zákona podle $\S 466$ odst. 2 trestního řádu.

Navrhovaná novela trestního řádu se též musela vypořádat s určováním místní příslušnosti soudu, který $\mathbf{v}$ př́ípravném řízení rozhoduje o stížnosti proti rozhodnutí státního zástupce nebo policejního orgánu podle § 146a trestního řádu. V př́ípadě evropského pověřeného žalobce nebyla změna trestního řádu nutná, nebot' tento bude mít postavení státního zástupce a podle návrhu nového § 34c odst. 1 zákona o státním zastupitelství bude státní zastupitelství, které bylo stanoveno jako místo výkonu funkce evropského pověřeného žalobce, považováno za státní zastupitelství, u kterého je evropský pověřený žalobce činný. Př́ślušnost soudu se tak bude určovat zcela shodně, jako u vnitrostátního státního zástupce působící u tohoto státního zastupitelství. Naopak evropský žalobce bude působit v ústředí EPPO a pokud by nahrazoval při vedení trestního řízení evropského pověřeného žalobce, je zcela správné, že novela stanoví určení místní př́slušnosti soudu shodně, tedy na soud, v jehož obvodu by byl činný evropský pověřený žalobce, který by byl jinak př́ślušný k výkonu dozoru nad zacho-

21 Bude tak na jednotlivých evropských žalobcích, aby při projednávání a schvalování jednacího řádu EPPO $\mathrm{v}$ rámci kolegia (viz čl. 21 odst. 1 a 2 nařízení o EPPO) na toto pamatovali a vnitrostátní specifika zohlednili. 
váváním zákonnosti v přípravném řízení. Obdobně bude postupováno i podle změny $\mathrm{v} \S 146 a$ odst. 3 trestního řádu, jde-li o stížností napadené rozhodnutí policejního orgánu $\mathrm{v}$ trestním řízení dozorovaném evropským žalobcem.

Jinak bude též i u věcí patřících do působnosti EPPO postupováno při určování místní příslušnosti soudů $\mathrm{v}$ přípravném řízení ve smyslu nálezu Ústavního soudu sp. zn. Pl. ÚS 4/14 ze dne 19. 4. 2019. ${ }^{22}$

S ohledem na zvláštní úpravu vnitrostátní bylo třeba stanovit orgán podávající návrh na povolení použití agenta. Právní úprava ponechává i pro trestní řízení v působnosti EPPO př́slušnost vrchního soudu, ale návrh bude podle novely § 158d odst. 4 trestního rrádu podávat sám evropský pověřený žalobce. Pro př́pad, že by evropský žalobce nahrazoval při vedení trestního řízení evropského pověřeného žalobce, je užito řešení již uvedené výše, a to že vrchním soudem bude ten, v jehož obvodu by byl činný evropský pověřený žalobce, který by byl jinak prííslušný $\mathrm{k}$ výkonu dozoru nad zachováváním zákonnosti v př́ípravném řízení. Navrhovaná právní úprava koresponduje s čl. 30 odst. 2 a 4 nařízení o EPPO.

Jelikož nemůže státní zastupitelství zasahovat do věcí v působnosti EPPO (viz čl. 4 a čl. 6 odst. 1 nařízení o EPPO), budou v těchto věcech rozhodnutí o nestíhání podezřelého podle $\S 159 \mathrm{~d}$ trestního řádu, o postoupení věci podle $\S 171$ trestního řádu a o zastavení trestního stíhání podle $\S 172$ trestního řádu vyloučena z dosahu zvláštního kasačního oprávnění nejvyššího státního zástupce podle $§ 174 a$ trestního řádu a EPPO tak nebude mít logicky ani povinnost tato rozhodnutí nejvyššímu státnímu zástupci doručovat ( $\$ 159 \mathrm{~d}$ odst. 3 a $§ 173$ a trestního řádu). Obdobný př́ístup byl zvolen i ohledně práva nejvyššího státního zástupce podat ve věci dovolání (viz nová úprava $v$ § 265d odst. 1 písm. a) a b) trestního řádu), nejvyšší státní zástupce nebude moci dovoláním zasahovat do věcí v působnosti EPPO, ale dovolání bude moci být podáno př́slušným orgánem EPPO.

Změn právní úpravy se dotknou i ustanovení § 265r a § 274 trestního řádu, týkající se účasti u veřejných zasedání $\mathrm{v}$ řízení o dovolání nebo $\mathrm{v}$ řízení o stížnosti o porušení zákona. Jak uvádí důvodová zpráva: ${ }^{23}$ "Úřad evropského veřejného žalobce bude činný ve stanovených př́padech až do ,finálního rozhodnutí ', tj. v rámci př́pravného řizení, rízeni pred soudem a v rízeni o opravných prostředcich, at už rádných nebo mimořádných. Je tedy vyloučeno, aby byla zachována možnost intervenovat v řizeni o dovolání a v ř́zení o stižnosti pro porušení zákona státnímu zástupci činnému u Nejvyššího státního zastupitelství. Opět i v tomto př́padě bude záviset na interní úpravě Úřadu, který orgán v rámci Úradu bude př́slušný k účasti na veřejných zasedánich konaných o podaném dovoláni nebo stižnosti pro porušení zákona."

V návaznosti na převzetí úkolů $v$ rámci trestního řízení ve vymezené oblasti ze strany EPPO bylo třeba provést i novelizace zákona o Rejstř́ku trestů a zákona o mezinárodní justiční spolupráci ve věcech trestních.

\footnotetext{
22 Jak již bylo uvedeno výše, vychází se prozatím z pracovního předpokladu, že evropští pověření žalobci budou působit při vrchních státních zastupitelstvích.

23 Sněmovní tisk č. 337, VIII. volební období, s. 42.
} 


\section{ZMĚNY DALŠÍCH PRÁVNÍCH PŘEDPISU゚}

V návaznosti na již výše uvedené změny bylo třeba provést změny v řadě dalších zákonů. $V$ některých př́padech se jedná o změny většího obsahového významu, v některých se jedná spíše o změny technického charakteru navazující na personální působení osob činných u EPPO. O některých změnách dalších právních předpisů již bylo pojednáno výše, pokud $\mathrm{k}$ tomu byla věcná souvislost.

\subsection{ZMĚNA TRESTNÍHO ZÁKONÍKU24}

V návaznosti na změnu provedenou $\mathrm{v} \S 12$ odst. 5 trestního řádu, která výslovně stanoví, že státním zástupcem se rozumí i evropský pověřený žalobce, evropský žalobce a evropský nejvyšší žalobce v rozsahu jejich působnosti podle nařízení o EPPO (viz výše), a současně v návaznosti na vlastní čl. 13 odst. 1 a čl. 28 odst. 4 nařízení o EPPO, bylo třeba na toto nové postavení výše uvedených žalobců reagovat i v rámci trestního zákoníku, a to ve stávajícím $§ 127$ odst. 1 písm. a) trestního zákoníku. Jestliže podle stávající právní úpravy uvedené ustanovení zařazuje státního zástupce do kategorie úředních osob, pak je třeba zcela obdobně toto postavení přiznat i výše uvedeným žalobcům. Legislativně technicky se pro tento účel vkládá do trestního zákoníku nový § 127a. Byt’ by bylo možné dovodit podřazení shora uvedených žalobců podle $\S 127$ odst. 1 písm. a) trestního zákoníku již na základě změny provedené v $\S 12$ odst. 5 trestního řádu (jedná se však o úpravu procesní, nikoliv hmotněprávní) a i jejich postavení vyplývajícího ze samotného nařízení o EPPO, tak s ohledem na právní jistotu je nepochybně vhodné, aby byla změna právní úpravy učiněna i na tomto místě. Evropský pověřený žalobce, evropský žalobce a evropský nejvyšší žalobce tak nebudou spadat do kategorie úřední osoby cizího státu nebo mezinárodní organizace podle $\S 127$ odst. 3 trestního zákoníku. V dalším je možné odkázat na existující odbornou literaturu k výkladu $§ 127$ trestního zákoníku, nebot’ toto ustanovení bude třeba vykládat i k těmto žalobcům obdobně. ${ }^{25}$

\subsection{ZMĚNY V OBLASTI PLATU A PRÁVA SOCIÁLNÍHO ZABEZPEČENÍ}

Změny právní úpravy provedené v zákoně č. 582/1991 Sb., o organizaci a provádění sociálního zabezpečení, ve znění pozdějších předpisů, v zákoně č. 589/1992 Sb., o pojistném na sociální zabezpečení a př́íspěvku na státní politiku zaměstnanosti, ve znění pozdějších předpisů, v zákoně č. 155/1995 Sb., o důchodovém pojištění, ve znění pozdějších předpisů, v zákoně č. 201/1997 Sb., o platu a některých dalších náležitostech státních zástupců a o změně a doplnění zákona č. 143/1992 Sb., o platu a odměně za pracovní pohotovost $\mathrm{v}$ rozpočtových a $\mathrm{v}$ některých dalších organizacích a orgánech, ve znění pozdějších předpisů, a v zákoně č. 187/2006 Sb., o nemocenském pojištění,

24 Zákon č. 40/2009 Sb., trestní zákoník, ve znění pozdějších předpisů.

25 ŠÁMAL, P. a kol. Trestni zákoník. 2. vyd. Praha: C. H. Beck, 2012, s. 1350 a násl. nebo DRAŠTíK, A. FREMR, R. - DURDÍK, T. - RƯŽIČKA, M. - SOTOLÁŘ, A. a kol. Trestní zákoník. Komentár. I. díl. Praha: Wolters Kluwer, a. s., 2015, s. 801 a násl. 
ve znění pozdějších předpisů, reagují na potřeby řešit situaci platového a sociálního zabezpečení evropských pověřených žalobců.

Podle čl. 96 odst. 6 nařízení o EPPO budou evropští pověření žalobci přijímáni jako zvláštní poradci v souladu s články 5, 123 a 124 Pracovního řádu pro ostatní zaměstnance ES. ${ }^{26}$ Podle tohoto ustanovení nařizení se dále má zajistit zavedení takových vhodných opatření, aby byla zachována práva evropských pověřených žalobců týkající se sociálního zabezpečení, důchodu a pojistného krytí podle vnitrostátního systému; rovněž se má zajistit, aby celková odměna evropských pověřených žalobců nebyla nižší, než by byla $v$ př́padě, že by zůstali pouze vnitrostátními žalobci. Je zdůrazněn požadavek na nesnižování sociálního standardu evropských pověřených žalobců oproti jejich postavení v domovském státě. Reaguje se tak na jejich specifické pracovní postavení dané pracovní smlouvou, kterou budou jako zvláštní poradci s EPPO uzavírat. ${ }^{27} \mathrm{Z}$ čl. 91 odst. 4 nařízení o EPPO pak plyne, že evropští pověření žalobci budou mít nárok na odměnu, která bude hrazena z rozpočtu EPPO. Odměna se bude stanovovat v pracovní smlouvě. Pokud by evropský pověřený žalobce působil pouze na částečný úvazek a ve zbytku by nadále aktivně působil jako státní zástupce, bude pobírat pouze poměrnou část platu státního zástupce.

Změny právní úpravy se netýkají evropských žalobců a evropského nejvyššího žalobce, nebot' tito budou podle čl. 96 odst. 1 nařízení o EPPO zaměstnaní jako dočasní zaměstnanci EPPO podle čl. 2 písm. a) Pracovního řádu pro ostatní zaměstnance ES. Budou tedy zaměstnaní na ,plný úvazek“ jako standardní zaměstnanci orgánu Evropské unie.

\section{ZÁVĚR}

Jelikož jsem se určitým způsobem podílel na přípravě shora uvedené právní úpravy, neměl bych to být já, kdo bude provádět její hlubší hodnocení. Proto i předmětem tohoto př́spěvku je (jak již uvedeno v úvodní části) seznámení čtenářů s podstatnými body navrhované právní úpravy a vysvětlení jejich smyslu a ozřejmění některých úvah, kterými se zpracovatelé řídili. Současně ale mám za to, že se povedlo připravit právní úpravu legislativně stručnou, ale současně racionálním způsobem upravující to podstatné, aby Česká republika mohla dostát svému závazku a umožnila plnou činnost EPPO i na jejím území. Současně je třeba vzít v úvahu, že osvědčení se navrhované právní úpravy v praxi, popř. její problémy budou vázány až na její finální podobu.

Je třeba uvést, že přijetím navrhované právní úpravy se zdaleka nevyčerpá okruh oblastí, které bude třeba řešit a aktuálně se řeší (např. samotný výběr evropských pověře-

26 Council Regulation No 31 (EEC), 11 (EAEC), laying down the Staff Regulations of Officials and the Conditions of Employment of Other Servants of the European Economic Community and the European Atomic Energy Community (OJ 45, 14. 6. 1962, p. 1385/62). Dostupné na: https://eur-lex.europa.eu/legal-content /EN/TXT/?uri=CELEX\%3A01962R0031-20140501.

27 Užití institutu zvláštních poradců na postavení evropských delegovaných žalobců vyplývá z nařízení o EPPO, ale zjevně nebylo zvoleno zcela št’astně. Tento institut se již podle svého názvu užival na působení osob jako poradců, nikoliv jako osob, které budou př́mo vykonávat působnost EPPO a tedy budou vykonavateli veřejné moci. 
ných žalobců, otázky výkonu spisové služby EPPO u příslušných státních zastupitelství, faktické zrrízení př́stupu do různých informačních systémů a databází, př̌edevším do informačního systému ETŘ, zajiššění činnosti evropských pověřených žalobců dostatečně jazykově vybaveným administrativním personálem atd.). Tyto však již nepředstavují oblast adaptace právního řádu a přesahují tak vymezené téma tohoto př́íspěvku.

Jak již bylo uvedeno shora, je aktuálně stav projednávání sněmovního tisku č. 337 takový, že dne 30.1. 2019 proběhlo první čtení a návrh projednal ústavně právní výbor, jako výbor garanční, a svým usnesením ze dne 10. 4. 2019 doporučil schválení návrhu a současně navrhl některé pozměňovací návrhy (viz sněmovní tisk č. 337/3). S ohledem na zatím předpokládané započetí činnosti EPPO na konci roku 2020 (viz čl. 120 nařízení o EPPO) ${ }^{28}$ a nutnost do této doby zajistit fungování činnosti EPPO po stránce personální, organizační a technické i na úrovni České republiky, by bylo vhodné (resp. nezbytné), aby navrhovaná právní úprava byla schválena a nabyla účinnosti co možná nejdř́íve. ${ }^{29}$

Mgr. Jiří Pavlík

Nejvyšší státní zastupitelství

jpavlik@nsz.brn.justice.cz

Zatím nejsou informace o tom, že by měl být tento termín výrazněji posunut.

29 Nepochybně se tak již nestihne v návrhu zákona předpokládané nabytí účinnosti od 1. 11. 2019 s výjimkou novelizace trestního zákoníku, která měla nabýt účinnosti již 6. 7. 2019. 